\title{
A BLOCKING JELENSÉG SZINOPTIKUS KLIMATOLÓGIAI VIZSGÁLATA AZ ATLANTI-EURÓPAI TÉRSÉGBEN
}

\author{
Iván Márk $^{(1)}$, Dezső Zsuzsanna ${ }^{(1)}$ (D), Bartholy Judit ${ }^{(1,2)}$ (D), Pongrácz $\operatorname{Rita}^{(1,2)}$ (D) \\ ${ }^{(1)}$ ELTE Meteorológiai Tanszék, 1117 Budapest, Pázmány Péter sétány 1/A \\ ${ }^{(2)}$ ELTE TTK Kiválósági Központ, 2462 Martonvásár, Brunszvik u. 2. \\ e-mail: ivanmark90@caesar.elte.hu,dezsozsuzsi@caesar.elte.hu, \\ bartholy@caesar.elte.hu, prita@nimbus.elte.hu
}

\section{Bevezetés}

A Napból érkező sugárzási energia a földfelszínen egyenlőtlenül oszlik el, ezért az Egyenlítő és a sarkvidékek között globális skálájú légköri és óceáni transzportfolyamatok biztosítják az energia kiegyenlítődését. A közepes szélességeken, az Egyenlítőtől a pólusok felé irányuló hőszállítás számottevő része az óceáni áramlások mellett a légköri transzportfolyamatok révén valósul meg (Trenberth és Caron, 2001). A mérsékelt övben a hosszú idő átlagában vett uralkodó szélirány, a nyugatról kelet felé irányuló légmozgás olykor deformációt szenved és meridionálissá válik. Amennyiben ez a jelenség hosszabb ideig (három naptól akár több hétig is) fennáll, akkor ún. blocking jelenségröl beszélünk, ami fajtájától függően tartósan csapadékos vagy aszályos időjárást okozhat. A felső-troposzférikus áramlási- és geopotenciálmező mintázatától függően beszélhetünk: (i) omega-blockingról, (ii) blokkoló anticiklonról, (iii) cut-off ciklonról és (iv) rex-blockingról.

\section{A blocking jelenség típusainak bemutatása}

A blocking különféle típusai a felső-troposzférikus geopotenciál-mezőben megjelenő alacsony- és magasnyomású központok különböző térbeli elhelyezkedésü konfigurációjaként azonosíthatók. Az alacsony- és magasnyomású légköri képződmények (azaz mérsékeltövi ciklonok és anticiklonok) egymáshoz viszonyított helyzete alapján osztályozzuk őket.

(i) Az omega-blocking egy anticiklon és két ciklon konfigurációt jelenít meg (1.ábra). A magasnyomású képződmény belsejében gyenge légmozgás, sok esetben igen jelentős szárazság, míg tőle délkeletre és délnyugatra az alacsony nyomású képződményekben csapadékos időjárás a jellemző.

(ii) A cut-off ciklon egy alacsonynyomású légköri képződmény: az 500 hPa-os nyomási szinten egy, a vezető áramlásról leszakadó, zárt cirkulációjú ciklonális örvény jön létre, melyet minden irányból magasabb geopotenciállal rendelkező területek vesznek körbe (2. ábra).

(iii) A blokkoló anticiklon egy magasnyomású légköri képződmény. Ez a jelenség hosszú napokon át tartó stagnáló időjárási helyzetet, télen gyakran hosszantartó ködöt, párásságot, míg nyáron szárazságot és magas talajközeli hőmérsékletet eredményez.

(iv) Az ún. rex-blocking egy olyan szinoptikus skálájú légköri jelenség, ahol a hömérsékleti mező megszokott zonális - a pólus felé csökkenő - elrendeződése (Fleming et al., 1990) megváltozik, és az északabbra fekvő területen egy pozitív, délebbre pedig egy negatív hőmérsékleti anomália jelenik meg. A légköri blocking ezen típusa szerkezetileg egy anticiklonból és egy ciklonból áll. A két nyomási képződmény egymáshoz viszonyított helyzete észak-déli irányú, s a magas légnyomású képződmény északabbra, míg az alacsony légnyomású délebbre helyezkedik el. 
Iván M., Dezső Zs., Bartholy J., Pongrácz R.:

A blocking jelenség szinoptikus klimatológiai vizsgálata az atlanti-európai térségben

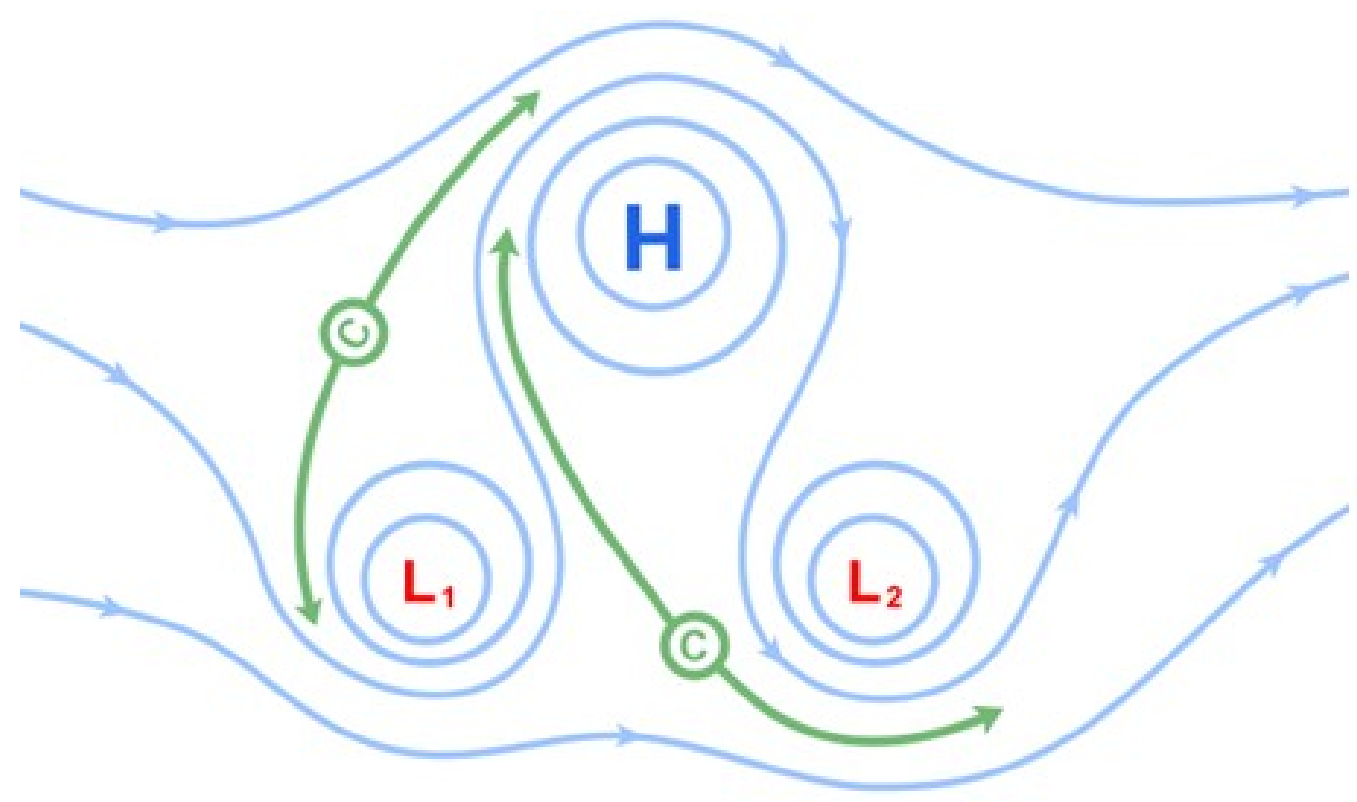

—Deformációs zóna

- $500 \mathrm{hPa}$ geopotenciális magasság

The coMet Program

1. ábra: Omega-blocking szerkezet, ahol L az alacsony nyomás, $\mathrm{H}$ a magas nyomás, a kék vonalak az áramvonalak az $500 \mathrm{hPa}$-os nyomási szinten, forrás: http://www.comet.ucar.edu/.

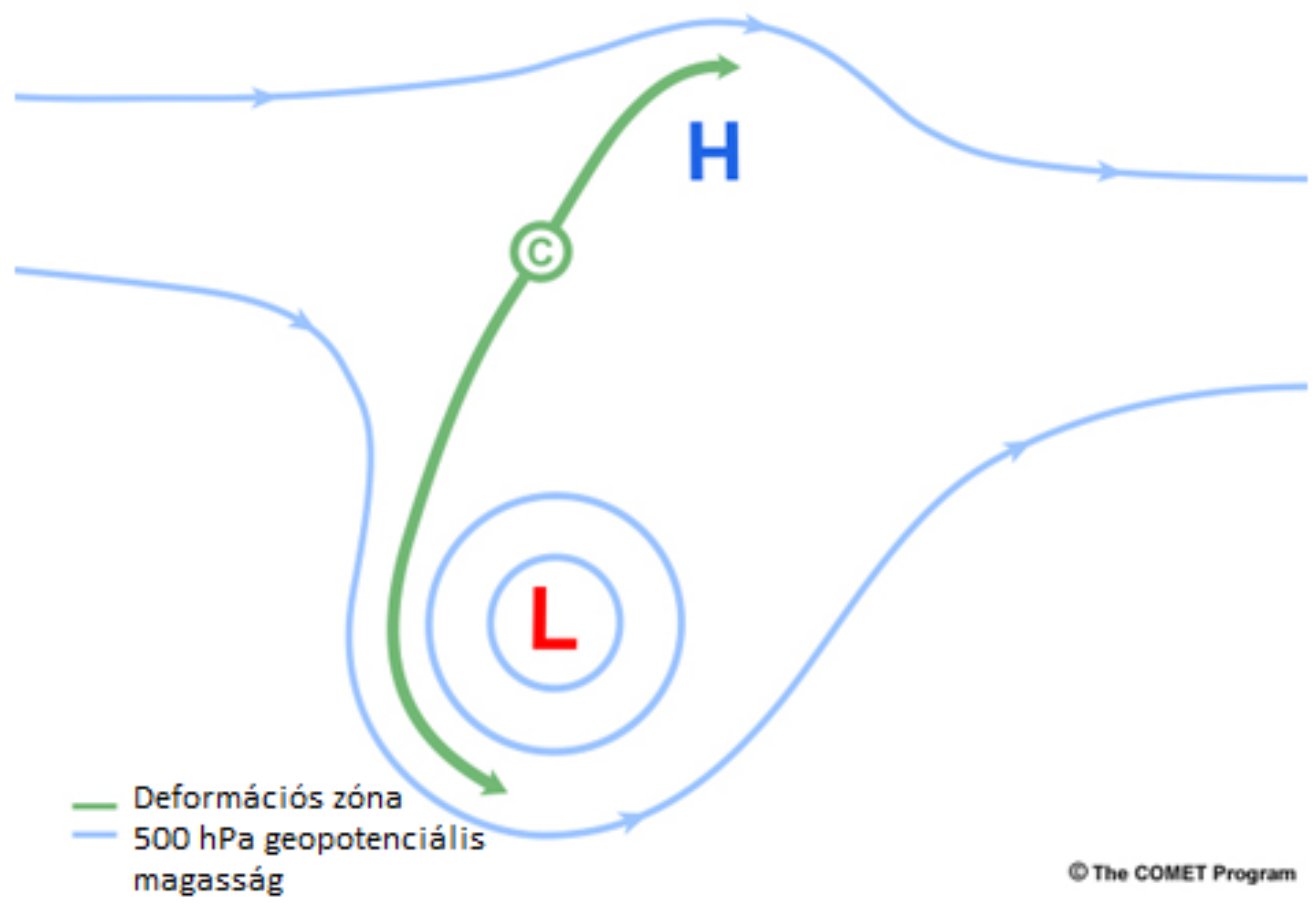

2. ábra: Cut-off ciklon szerkezet, ahol L az alacsony nyomás, $\mathrm{H}$ a magas nyomás, a kék vonalak az áramvonalak az 500 hPa-os nyomási szinten, forrás: http://www.comet.ucar.edu/. 
Iván M., Dezső Zs., Bartholy J., Pongrácz R.:

A blocking jelenség szinoptikus klimatológiai vizsgálata az atlanti-európai térségben

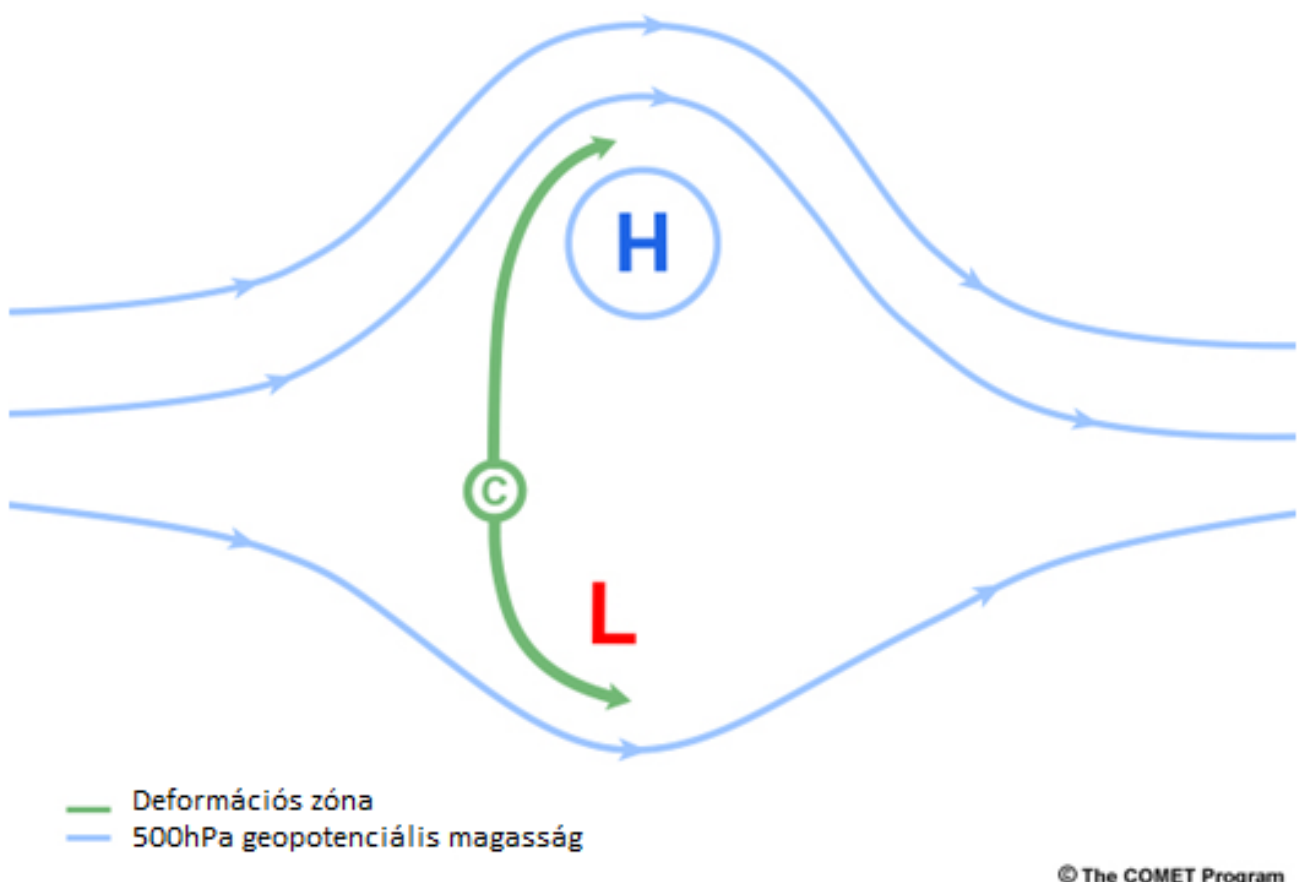

3. ábra: Blokkoló anticiklon szerkezet, ahol L az alacsony nyomás, $\mathrm{H}$ a magas nyomás, a kék vonalak az áramvonalak az $500 \mathrm{hPa}$-os nyomási szinten, forrás: http://www.comet.ucar.edu/.

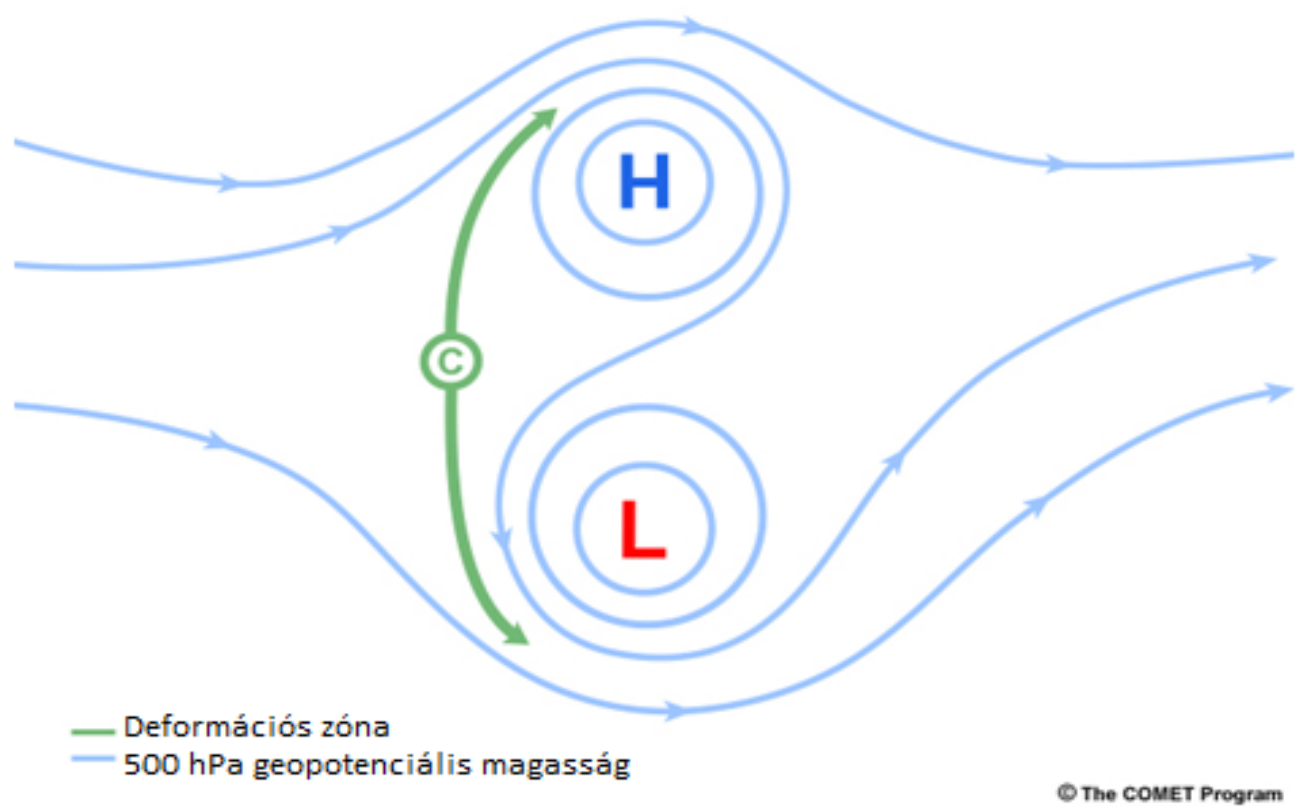

4. ábra: Rex-blocking szerkezet, ahol L az alacsony nyomás, $\mathrm{H}$ a magas nyomás, a kék vonalak az áramvonalak az $500 \mathrm{hPa}$-os nyomási szinten, forrás: http://www.comet.ucar.edu/.

A továbbiakban bemutatunk néhány, a blocking jelenség jellemzésére kidolgozott ún. blocking-indexet, s azok számítási módszereit. 


\section{A felhasznált adatbázis}

A számításainkat az $1^{\circ}$ horizontális rácsfelbontású ERA-Interim reanalízis adatokkal végeztük el, melyeket az ECMWF ${ }^{1}$ szabadon hozzáférhető adatbázisából töltöttünk le. A vizsgálatainkat az 5. ábrán látható atlanti-európai térségre végeztük el az 1981-2000 közötti időszakra.

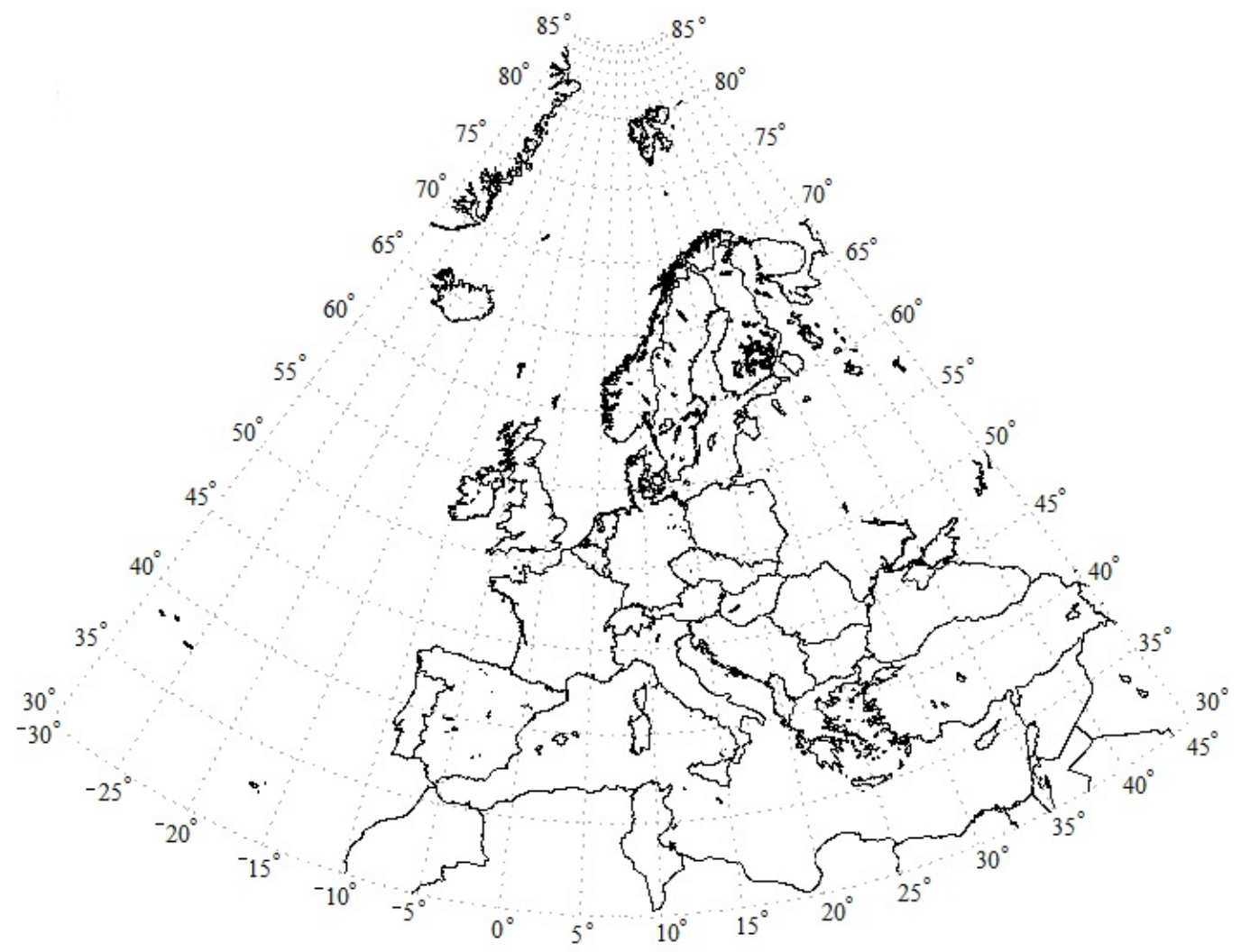

5. ábra: A vizsgálati terület északi és déli határai: É.sz. $85^{\circ}$ és $30^{\circ}$, nyugati és keleti határa: Ny.h. $30^{\circ}$ és K.h. $45^{\circ}$.

\section{Az alkalmazott blocking indexek bemutatása}

A blocking jelenség egzisztenciájának és erősségének vizsgálatára többféle mérőszámot, ún. blocking-indexet is kidolgoztak. Az általunk alkalmazott indexek, számítási módszerek (Tibaldi és Molteni, 1990; Tibaldi et al., 1993; Trigo et al., 2004; Schalge et al., 2011) mindegyike ugyanazt az elvet követi, azonban kisebb változtatásokat tartalmaznak. A blockingindexek, számítási módszerek alapelve az, hogy egy adott hosszúsági fok mentén vizsgáljuk az $500 \mathrm{hPa}$-os föizobár-szint geopotenciális magasságának gradiensét egy központi földrajzi szélességtől északi és déli irányban. A 6. ábra a Tibaldi és Molteni (1990) által kidolgozott módszert (TM90) szemlélteti. A geopotenciális magassági gradiensek $\left(\mathrm{GHGN}^{2}\right.$ és $\mathrm{GHGS}^{3}$ ) kiszámítása északi, illetve déli irányban rendre az (1) és (2) egyenlet alapján történik.

$$
G H G N=\frac{Z\left(\Phi_{n}\right)-Z\left(\Phi_{0}\right)}{\Phi_{n}-\Phi_{0}}
$$

\footnotetext{
${ }^{1}$ European Centre for Medium-Range Weather Forecasts: Európai Középtávú Időjárási Előrejelzési Központ

${ }^{2}$ Geopotential Height Gradient North: északi irányú geopotenciális magassági gradiens

${ }^{3}$ Geopotential Height Gradient South: déli irányú geopotenciális magassági gradiens
} 


$$
G H G S=\frac{Z\left(\Phi_{0}\right)-Z\left(\Phi_{S}\right)}{\Phi_{0}-\Phi_{S}}
$$

ahol:

$$
\begin{aligned}
& \Phi_{n}=80^{\circ}+\Delta \\
& \Phi_{0}=60^{\circ}+\Delta \\
& \Phi_{s}=40^{\circ}+\Delta \\
& \Delta=4^{\circ}, 0^{\circ},-4^{\circ}
\end{aligned}
$$

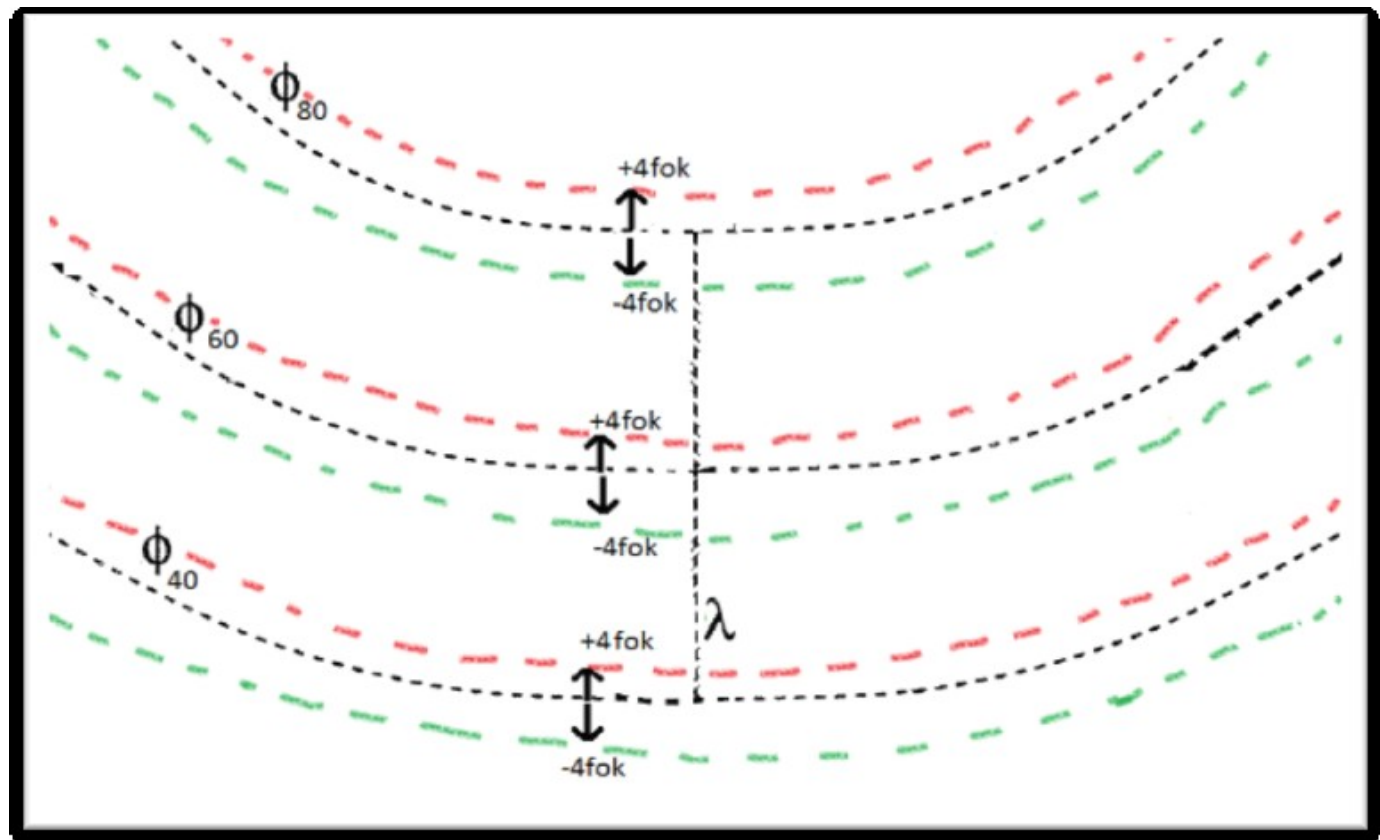

6. ábra: A TM90 blocking-index számítási módszer során vizsgált földrajzi szélességek Tibaldi és Molteni (1990) alapján.

A 6. ábrán látható három kitüntetett szélesség: a $40^{\circ}, 60^{\circ}, 80^{\circ}$ földrajzi szélesség; adott $\lambda$ hosszúsági kör mentén e szélességi körök által kijelölt pontokban számítjuk ki az $500 \mathrm{hPa}$-os nyomási szint geopotenciális magasságának $\left(\Phi_{80}, \Phi_{60}, \Phi_{40}\right)$ különbségét az (1) és (2) egyenlet alapján. Felhasználva a $\Delta$ három különböző értékét, mind az északi, mind a déli tartományra három-három különbséget kapunk, melyek közül a legnagyobb északit és legnagyobb délit összevetjük az előre meghatározott küszöbértékekkel, azaz rendre a (3) és a (4) egyenlettel. Ha mind az északi, mind a déli értékek megfelelnek ezeknek a kritériumoknak, akkor a vizsgált napon az adott $\lambda$ hosszúsági kör mentén a definiált mértékü anomália lépett fel. Ahhoz, hogy ezt a folyamatot blocking jelenségnek tekintsük, legalább négy egymást követő napon teljesülni kell ezeknek az anomália kritériumoknak.

$$
\begin{aligned}
& \text { GHGN }<-\frac{10 \mathrm{gpm}}{\text { szélességi fok }} \\
& \text { GHGS }>\frac{0 \mathrm{gpm}}{\text { szélességi fok }}
\end{aligned}
$$

A szakirodalmi forrásokban fellelhető számítási módszerek többsége a különbségek számításában, azaz a kitüntetett szélességek megválasztásában és a $\Delta$ értékeiben tér el egymástól (1. táblázat). 
Iván M., Dezső Zs., Bartholy J., Pongrácz R.:

A blocking jelenség szinoptikus klimatológiai vizsgálata az atlanti-európai térségben

1. táblázat: A különböző blocking-index számítási módszerek során alkalmazott paraméter-értékek.

\begin{tabular}{|c|c|c|c|c|c|}
\hline Szakirodalom & $\begin{array}{c}\text { Módszer } \\
\text { rövid neve }\end{array}$ & $\begin{array}{c}\text { GHGN } \\
\text { alapszélessége }\end{array}$ & $\begin{array}{c}\text { GHGS } \\
\text { alapszélessége }\end{array}$ & $\Delta$ & $\begin{array}{c}\text { Kitüntetett } \\
\text { szélességek }\end{array}$ \\
\hline Tibaldi \& Molteni, 1990 & TM90 & $20^{\circ}$ & $20^{\circ}$ & $4^{\circ}$ & $80^{\circ} ; 60^{\circ} ; 40^{\circ}$ \\
\hline Tibaldi \& Molteni, 1990 & TM90_15 & $15^{\circ}$ & $15^{\circ}$ & $4^{\circ}$ & $75^{\circ} ; 60^{\circ} ; 45^{\circ}$ \\
\hline Tibaldi et al., 1993 & TTNP93 & $20^{\circ}$ & $20^{\circ}$ & $3.75^{\circ}$ & $80^{\circ} ; 60^{\circ} ; 40^{\circ}$ \\
\hline Trigo et al., 2004 & TRIGO4_2.5 & $17,5^{\circ}$ & $20^{\circ}$ & $5^{\circ}$ & $77,5^{\circ} ; 60^{\circ} ; 40^{\circ}$ \\
\hline Trigo et al., 2004 & TRIGO4_5 & $17,5^{\circ}$ & $20^{\circ}$ & $2.5^{\circ}$ & $77,5^{\circ} ; 60^{\circ} ; 40^{\circ}$ \\
\hline Schalge et al., 2011 & BRK11 & $18,75^{\circ}$ & $21,25^{\circ}$ & $3,75^{\circ}$ & $78,75^{\circ} ; 60^{\circ} ; 38,75^{\circ}$ \\
\hline
\end{tabular}

\section{Eredmények}

A vizsgálatunk során az 1. táblázatban feltüntetett összes módszer segítségével két egymást követő tízéves periódus (1981-1990 és 1991-2000) minden napjára, a vizsgált tartomány mindenegyes hosszúsági körére meghatároztuk a blocking-index értékét.

TM90

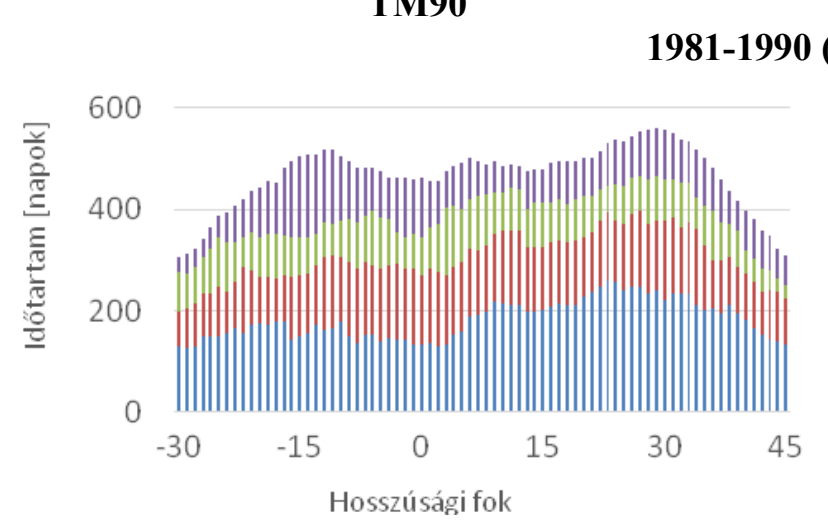

TRIGO4_5

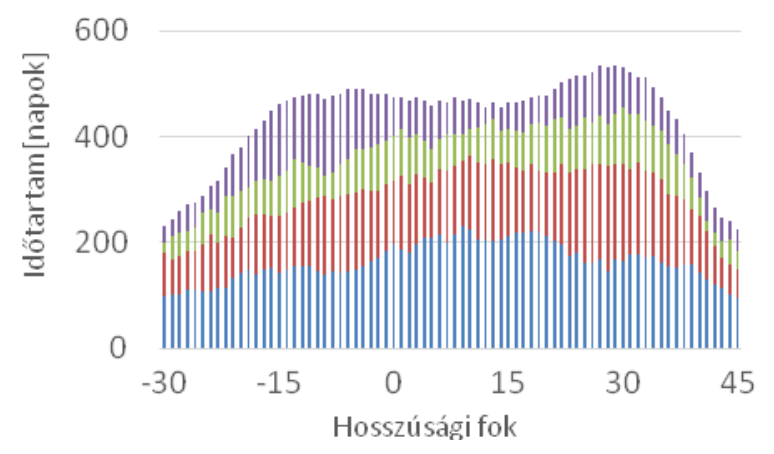

1991-2000 (2. időszak)
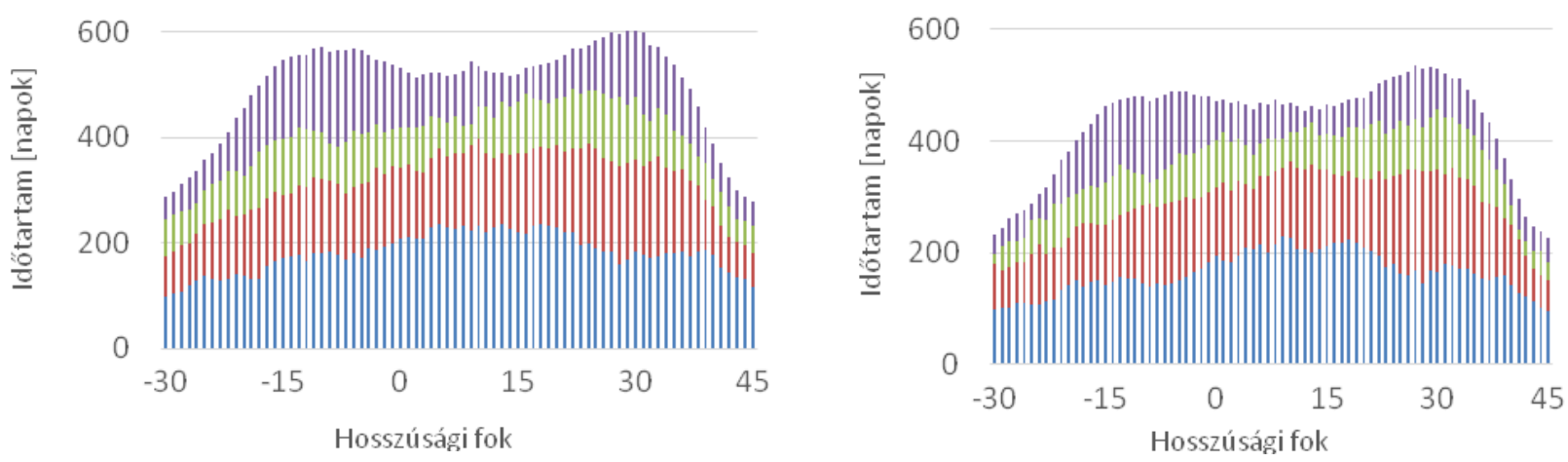

Időtartam (napok)

1-3 $\square$ 4-5

6-7

8-30

7. ábra: A TM90 (balra) és TRIGO4_5 (jobbra) módszerrel meghatározott blocking események földrajzi eloszlása és az időtartam szerinti gyakorisága.

Ezután megvizsgáltuk, hogy egy-egy rácspontban a kapott gradiensek hány egymást követö napon feleltek meg mind a (3), mind a (4) kritériumnak, tehát egy-egy blocking esemény hány napig állt fenn. Jelen tanulmányban a TM90 (Tibaldi és Molteni, 1990) és a TRIGO4_5 (Trigo et al., 2004) módszerrel kapott eredmények kerülnek bemutatásra a 
7. ábrán. A vizsgálat mind a két időszakban tíz-tíz évre vonatkozik, így ha például vesszük, a TRIGO4_5 módszert és a második időszakot, akkor az x-tengely mentén választott 15 . keleti hosszúsági fokon a hozzá tartozó y-tengelybeli érték 450 körüli. Ez azt jelenti, hogy a tíz év alatt ezzel a módszerrel, 450 napon volt detektálható blocking jelenség. Ez a 450 nap a különböző időhosszúságú blocking események összege a példaként választott 15 . keleti hosszúsági fokon.

Az látható a grafikonokon, hogy a különböző színnel jelölt különböző időtartamú anomáliák előfordulási gyakoriságát hogyan befolyásolja a földrajzi elhelyezkedés. Mindkét módszerrel arra az eredményre jutottunk, hogy a K.h. $30^{\circ}$ körül a leggyakoribbak a blocking események, és megjelenik egy másodlagos maximum a Ny.h. $10^{\circ}$ körül. Míg az elöbbi keleti lokális maximum túlnyomó részben szárazföldi felszín felett helyezkedik el, addig a nyugati lokális maximum óceáni vízfelszín felett található. Mindezek mellett a rövidebb időtartamú anomáliák gyakorisága nagyobb, mint a hosszabb időtartamú anomáliáké.

A két időszak eltérő sajátosságait vizsgálva látható, hogy a vizsgálati terület keleti oldalán a 4-5 napos, illetve a 6-7 napos anomáliák gyakorisága megnövekedett, míg az 1-3 napos időhosszúságú anomáliák gyakorisága csökkent ( 8 . ábra). Tehát összességében a vizsgált két évtized alapján gyakoribbá váltak a blocking események (amiről definíció szerint akkor beszélünk, ha az anomália legalább három napig fennáll). Ezzel szemben a vizsgálati tartomány nyugati oldalán csak kisebb mértékü változás volt tapasztalható.

Változások: 2. időszak - 1. időszak

TM90

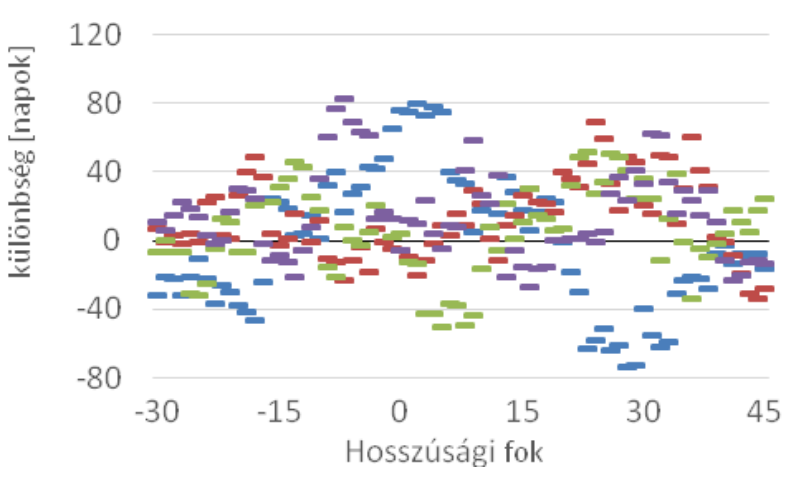

\section{TRIGO4 5}

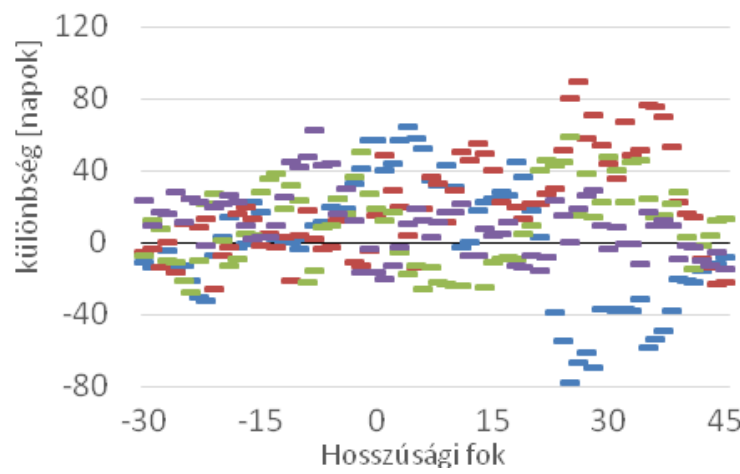

Időtartam (napok)

1-3 4-5

6-7

8-30

8. ábra: A TM90 (balra) és TRIGO4_5 (jobbra) módszerrel meghatározott blocking események földrajzi eloszlásában megjelenő változás a két 10 éves időszak vonatkozásában.

\section{Összefoglalás}

Az eredmények alapján látható, hogy a felszín óceáni vagy szárazföldi jellege, és e két felszíntípus adott hosszúsági kör menti egymáshoz viszonyított aránya nagymértékben befolyásolhatja az anomáliák fennmaradását, azaz a blocking helyzetek időtartamát. A két vizsgált évtized összevetése során látható volt, hogy a szárazföldi felszínek felett jóval nagyobb mértékủ változékonyság volt detektálható, mint az óceáni vízfelszínek felett.

Fontos hangsúlyozni, hogy az eredmények mindössze két évtizedre, az 1981-1990 és az 1991-2000 közötti időszakra vonatkoznak, de a blocking jelenségkörben tapasztalható változékonyság és az esetleges hosszabb távú tendenciák alaposabb elemzéséhez hosszabb időszak vizsgálatára lenne szükség. Ezért azt tervezzük, hogy a kutatásainkat - más adatbázisok felhasználásával - a teljes XX. évszázadra kiterjesztjük. 


\section{Köszönetnyilvánítás}

Kutatásainkat a Nemzeti Kutatási, Fejlesztési és Innovációs Alap K120605 és K-129162 számú projektjei, az Európai Regionális Fejlesztési Alap Széchenyi 2020 programja az AgroMo projekt (GINOP-2.3.2-15-2016-0028) keretében, az Emberi Erőforrások Minisztériuma az ELTE Felsőoktatási Intézményi Kiválósági Program (1783-3/2018/FEKUTSRAT) keretében, valamint az MTA Bolyai János Kutatási Ösztöndíja támogatta.

\section{Hivatkozások}

Fleming, E.L., Chandra, S., Barnett, J.J., Corney, M., 1990: Zonal Mean temperature, pressure, zonal wind and geopotential height as functions of latitude. Advances in Space Research, 10: 11-59. https://doi.org/10.1016/0273-1177(90)90386-E

Tibaldi, S., Molteni, F., 1990: On the operational predictability of blocking. Tellus, 42A: 343-365. https://doi.org/10.1034/j.1600-0870.1990.t01-2-00003.x

Tibaldi, S., Tosi, E., Navarra, A., Pedulli, L., 1993: Northern and Southern Hemisphere Seasonal Variability of Blocking Frequency and Predictability. Monthly Weather Review, 122: 1971-2003. https://doi.org/10.1175/1520-0493(1994)122<1971:NASHSV >2.0.CO;2

Trenberth, K.E., Caron, J.M., 2001: Estimates of Meridional Atmosphere and Ocean Heat Transports. Journal of Climate, 1: 3433-3443. https://doi.org/10.1175/15200442(2001)014<3433:EOMAAO $>2.0 . \mathrm{CO} ; 2$

Trigo, R.M., Trigo, I.F., DaCamara, C.C., Osborn, T.J., 2004: Winter blocking episodes in the European-Atlantic sector: climate impacts and associated physical mechanisms in the NCEP reanalysis. Climate Dynamics, 23: 17-28. https://doi.org/10.1007/s00382-004-04104

Schalge, B., Blender, R., Fraedrich, K., 2011: Blocking Detection Based on Synoptic Filters. Advances in Meteorology, 2011: 717812, 11p. https://doi.org/10.1155/2011/717812

\section{ORCID}

Dezsö Zs. (i) https://orcid.org/0000-0003-1325-1303

Bartholy J. (D) https://orcid.org/0000-0002-3911-7981

Pongrácz R. ID https://orcid.org/0000-0001-7591-7989 